\title{
Phenotyping for drought adaptation in wheat using physiological traits
}

\author{
Philippe Monneveux ${ }^{1 *}$, Ruilian Jing $^{2}$ and Satish C. Misra ${ }^{3}$ \\ 1 International Potato Center, Lima, Peru \\ ${ }^{2}$ Chinese Academy of Agricultural Sciences, Beijing, China \\ ${ }^{3}$ Agharkar Research Institute, Pune, India
}

\section{Edited by:}

Jean-Marcel Ribaut, Generation Challenge Programme, Mexico

\section{Reviewed by:}

Uener Kolukisaoglu, University of Tuebingen, Germany

Larry Butler, Generation Challenge

Program, Mexico

${ }^{*}$ Correspondence:

Philippe Monneveux, Research

Management Officer, International

Potato Center, Apartado 1558,

Lima 12, Peru.

e-mail: p.monneveux@cgiar.org
Wheat (Triticum spp) is one of the first domesticated food crops. It represents the first source of calories (after rice) and an important source of proteins in developing countries. As a result of the Green Revolution, wheat yield sharply increased due to the use of improved varieties, irrigation, pesticides, and fertilizers. The rate of increase in world wheat production, however, slowed after 1980, except in China, India, and Pakistan. Being adapted to a wide range of moisture conditions, wheat is grown on more land area worldwide than any other crop, including in drought prone areas. In these marginal rain-fed environments where at least $60 \mathrm{~m}$ ha of wheat is grown, amount and distribution of rainfall are the predominant factors influencing yield variability. Intensive work has been carried out in the area of drought adaptation over the last decades. Breeding strategies for drought tolerance improvement include: definition of the target environment, choice and characterization of the testing environment, water stress management and characterization, and use of phenotyping traits with high heritability. The use of integrative traits, facilitated by the development and application of new technologies (thermal imaging, spectral reflectance, stable isotopes) is facilitating high throughput phenotyping and indirect selection, consequently favoring yield improvement in drought prone environments.

Keywords: genetic resources, phenotyping traits, wheat, indirect selection, drought tolerance

\section{GENERAL INFORMATION IMPORTANCE OF WHEAT IN THE HUMAN DIET}

Wheat (Triticum spp) is one of the first domesticated food crops and, for 8000 years, has been the basic staple food of major civilizations of Europe, West Asia, and North Africa. Today, wheat continues to be an important food grain source for humans, and is a close third to rice and corn in total world production. Approximately two-thirds of the wheat produced is used for human food and about one-sixth for livestock feed. Industrial uses, seed requirements, and post-harvest losses account for the remainder. Wheat is used to produce a large variety of foods including many kinds of bread, cakes, noodles, crackers, breakfast foods, biscuits, and confectionary items. The protein content of wheat is in the range 12-16 percent and lipid content 1.5-2.0 percent.

World wheat production increased at a rate of 3.3 percent per year between 1949 and 1978. Increases at the start of this period were due to both an expansion of production area and increased yields. However, starting in the 1960s, yield increases came mainly from the use of improved varieties and a greatly expanded use of irrigation, pesticides, and fertilizers. The rate of increase in world wheat production slowed to 1.5 percent per year between 1982 and 1991, one exception being China, which maintained a rate of increase in production of 2.6 percent per year and became the world's largest wheat producer. Also, wheat production increased at nearly 3 percent per year in India and Pakistan during the same period.

Today, world wheat production is 626 million tons [Food and Agriculture Organization of the United Nations (FAO), 2007]. World leaders in order of production (all of the following figures are in million tons) are China (109), India (75.8), United States of America (55.8), Russian Federation (49.4), and France (32.8). Wheat is the dominant grain of world commerce. The five top exporters are USA (32.9), Canada (17.6), the European Community (16.5), Australia (14.7), and Argentina (9.6). The five top importers in 2007 were Brazil (6.6), Italy (6.2), Egypt (5.9), Japan (5.3), and Algeria (5.8).

\section{HISTORY OF THE CROP, CULTIVATED AREA, AND YIELD PERFORMANCE UNDER OPTIMAL CONDITIONS}

Wheat is believed to have been domesticated in southwestern Asia (Gupta, 2004). Some of the earliest remains of the crop have been found in Syria, Jordan, and Turkey (Pasternak, 1998). Primitive relatives of present-day wheat have been discovered in some of the oldest excavations of the world in eastern Iraq, dating back 9000 years. Bread wheat is known to have been grown in the Nile valley from $5000 \mathrm{BC}$, and was later cultivated in other regions (e.g., the Indus and Euphrates valleys from 4000 BC, China from 2500 BC, and Europe from $2000 \mathrm{BC}$ ). It was introduced into the American continent around 1520. 
Today, bread or common wheat (T. aestivum L) represents more than 90 percent of total wheat production. Several classes of bread wheat can be distinguished (hard red spring, hard red winter, soft red winter, hard white, and soft white) according to grain characteristics. Durum wheat or macaroni wheat (T turgidum subsp durum (Desf) Husnot) represents around 5 percent of global wheat production, i.e., 30 million tons. Durum wheat grain is hard, translucent, and large. The protein content can be as high as 18 percent. When durum is milled, the endosperm is ground into a granular product called "semolina," used for premium pastas and breads. Due to its high level of tolerance to terminal drought, most durum wheat is grown in Mediterranean environments. The remaining part of the wheat growing area is distributed among the diploid species einkorn, the tetraploid species emmer, poulard, polish and timopheevi, and the hexaploid species spelt, club, compact and macha (Table 1).

Being adapted to a wide range of moisture conditions from xerophytic to littoral, wheat is grown on more land area worldwide than any other crop. About three-quarters of the land area where wheat is grown receives between 375 and $875 \mathrm{~mm}$ of annual precipitation, but wheat can be grown in locations where precipitation ranges from 250 to $1750 \mathrm{~mm}$. The optimum growing temperature is about $25^{\circ} \mathrm{C}$, with minimum and maximum growth temperatures of $3-4^{\circ} \mathrm{C}$ and $30-32^{\circ} \mathrm{C}$, respectively (Briggle and Curtis, 1987). Classification into spring or winter wheat traditionally refers to the season during which the crop is grown. For winter wheat, heading is delayed until the plant experiences a period of cold winter temperatures $\left(0-5^{\circ} \mathrm{C}\right)$. It is planted in the autumn to germinate and develop into young plants that remain in the vegetative phase during the winter, and resume growth in early spring. This provides the advantage of using autumn moisture for germination and making effective use of early spring sunshine, warmth, and rainfall. Spring wheat, as the name implies, is usually planted in the spring and matures in late summer, but can be sown in autumn in countries that experience mild winters, such as in South Asia, North Africa, and the Middle East.

During the past 50 years, most of the yield progress in wheat has been due to the gradual replacement of traditional tall cultivars by dwarf and fertilizer-responsive varieties (Donmez et al., 2001; Brancourt-Hulmel et al., 2003; Jiang et al., 2003). Reducing height increased the proportion of carbon partitioned to grain and increased the harvest index (HI). It simultaneously reduced the risk of yield penalties caused by lodging. Most experiments analysing the effects of genetic improvement on yield found that, while selecting for higher-yielding cultivars, wheat breeders have consistently increased the number of grains per unit land area (Calderini et al., 1999). This is a consequence of a higher survival of floret primordia, the number of potential florets per spike remaining similar (Slafer and Andrade, 1993). It is likely to be due

Table 1 | Cultivated species (C) within the Triticum genus, and their wild relatives (W) (Source: van Slageren, 1994).

\begin{tabular}{|c|c|c|c|}
\hline Sections and species & \multicolumn{2}{|c|}{ Common name } & Regions of cultivation \\
\hline \multicolumn{4}{|l|}{ Section Monococca Flaksb } \\
\hline \multicolumn{4}{|l|}{ Triticum monococcum L } \\
\hline Subsp. monococcum & Einkorn & C & Mountainous areas (France, Morocco, the former Yugoslavia, Turkey) \\
\hline Subsp. aegilopoides (Link) Thell & & W & \\
\hline Triticum urartu Tumanian ex Gandilyan & & W & \\
\hline \multicolumn{4}{|l|}{ Section Dicoccoidea Flaksb } \\
\hline \multicolumn{4}{|l|}{ Triticum turgidum } \\
\hline Subsp. turgidum & Poulard & C & Mediterranean countries \\
\hline Subsp. carthlicum (Nevski in Kom) Á Löve \& D Löve & & C & \\
\hline Subsp. dicoccum (Schrank ex Schübler) Thell & Emmer & C & Yemen, India, Morocco, Spain, Albania, Turkey, Italy \\
\hline Subsp. durum (Desf) Husnot & Durum & C & \\
\hline Subsp. paleocolchicum (Menabde) Á Löve \& D Löve & & W & \\
\hline Subsp. polonicum (L) Thell & Polish & $\mathrm{C}$ & Mediterranean countries \\
\hline Subsp. turanicum (Jakubz) Á Löve \& D Löve & & W & \\
\hline Subsp. dicoccoides (Körn ex Asch \& Graebner) Thell & & W & \\
\hline \multicolumn{4}{|l|}{ Triticum timopheevii (Zhuk) Zhuk } \\
\hline Subsp. timopheevii & Timopheevi & C & Georgia \\
\hline Subsp. armeniacum (Jakubz) MacKey & & W & \\
\hline \multicolumn{4}{|l|}{ Section Triticum } \\
\hline \multicolumn{4}{|l|}{ Triticum aestivum L } \\
\hline Subsp. aestivum & Bread & C & \\
\hline Subsp. compactum (Host) MacKey & Compact & C & Alpine countries and Southern Europe \\
\hline Subsp. macha (Dekapr \& Menabde) MacKey & & C & Caucasus area \\
\hline Subsp. spelta (L) Thell & Spelt & C & Northern and Central Europe \\
\hline Subsp. sphaerococcum (Percival) MacKey & Club & C & India \\
\hline
\end{tabular}


to pleiotropic effects on spike fertility of the two most commercially important gibberellic acid (GA)-insensitive dwarfing genes $R h t-B 1 b$ and Rht-D1b (Flintham et al., 1997). Although there was an increase in grain number per $\mathrm{m}^{2}$, there was no reduction of grain weight, probably because photosynthetic capacity during grain filling together with pre-anthesis assimilate reserves exceed the demands of the growing wheat grains during post-anthesis (Borras et al., 2004).

Since the HI in most modern cultivars seems to be close to its biological maximum, i.e., 60 percent, further genetic gain in yield potential is expected to come from biomass increases (Shearman et al., 2005). Such increases have started to be reported in spring wheat (Reynolds et al., 1999) and winter bread wheat (Shearman et al., 2005). A biomass increase of about 10 percent has been reported in spring wheat, associated with the introduction of the long arm of chromosome 7D from the wheat wild relative Lophopyrum elongatum (Reynolds et al., 2001a; Monneveux et al., 2003). CIMMYT (Centro Internacional de Mejoramiento de Maíz y Trigo; the International Maize and Wheat Improvement Center) is exploring several approaches to exploit the excess photosynthetic capacity, like the multi-ovary characteristic which causes a single floret to set up to four kernels instead of just the usual one (Reynolds et al., 2005).

This requires, however, a good knowledge of the genetic and genomic resources available.

\section{GENETIC AND GENOMIC RESOURCES Genetic resources}

Wheat belongs to the Triticum genus, family Poaceae Barnhart, subfamily Pooideae, tribe Triticeae Dumort, subtribe Triticinae Griseb (van Slageren, 1994). Kihara (1919) and Sax (1922) showed that, in the genus Triticum, there are three different genomes, each composed of seven chromosomes. Both genera Aegilops and Triticum (6 species and 17 subspecies) belong to a complex of wild and domesticated species of which the allopolyploid members evolved via hybrid speciation (Kimber and Sears, $1987)$, which have the same base chromosome number $(n=7)$, and can be divided into three ploidy levels (i.e., diploid $2 n=14$, tetraploid $2 n=28$, and hexaploid $2 n=42$ ). Consequently, the available genepool of wheat is exceptionally wide (Zaharieva and Monneveux, 2006). As defined by Von Bothmer et al. (1992), the primary genepool consists of the cultivated and wild forms of a crop species. Gene transfer in the primary genepool is considered to be easy. The secondary genepool includes coenospecies from which gene transfer is possible but difficult, while the tertiary gene pool is composed of species from which gene transfer is very difficult.

Genetic resources have been categorized by Frankel (1975) as modern cultivars in current use, obsolete cultivars (i.e., the elite cultivars of the past, often found in the pedigrees of modern cultivars), landraces, wild relatives of the crop, genetic and cytogenetic stocks, and breeding lines. Today, CIMMYT's wheat germplasm bank holds more than 114,000 accessions, including parental and advanced breeding lines, cultivars and landraces, and more than 13,000 wild relatives from various regions of the world. Wheat genetic stocks involving translocation and substitution lines and produced by different institutions have been collected through a project supported by the Generation Challenge Programme (GCP), and are stored at CIMMYT.

\section{Genomic resources}

To address the need for general access to genetic maps, the International Triticeae Mapping Initiative (ITMI) was launched in 1989, to ensure that such maps would be available as a public good (Gustafson et al., 2004). Mapping using restriction fragment length polymorphisms (RFLPs) was conducted by scientists in several countries (McGuire and Qualset, 1997). As it became clear that resources for functional genomics, such as expressed sequence tags (ESTs), were the next critical need, ITMI created the International Triticeae EST Cooperative (ITEC). ITEC produced some 24,000 ESTs and mapped unigenes to chromosome bins defined by a set of deletion stocks. Then, a project on "The structure and function of the expressed portion of the wheat genomes" known as "wEST," funded by the USA's National Science Foundation (NSF) Plant Genome Research Program along with support from the collaborating institutions, developed several activities such as complementary DNA (cDNA) library development, EST production, deletion stock characterization (Qi et al., 2003) and mapping, and coordination of individual chromosome maps. Project investigators and members of the international scientific community are free to use the ESTs for gene discovery and utilization. The ESTs are available from the Wheat Genomics Resource Repository-a collaboration between the United States Department of Agriculture (USDA) and the University of California, Davis, USA. It is now feasible to envisage the development of single nucleotide polymorphism (SNP) markers in wheat, due to the explosion in the availability of ESTs. The hexaploid nature of the wheat genome makes such analysis more complex than it would be in species with simple genomes. As an open international consortium of institutions (public and private), ITMI is now attempting to mine the contigs in a coordinated way, pooling information on validated SNPs and avoiding duplication of effort. Information on progress in this project can be found at: http://wheat.pw.usda.gov/ITMI/ WheatSNP/

\section{RATIONALE FOR DEVELOPING DROUGHT RESEARCH IN WHEAT}

There has been a significant increase in the productivity of wheat due to the application of Green Revolution technology. This has resulted in a doubling and tripling of wheat production in many environments, most notably in irrigated areas. In these locations, the high-yielding semi-dwarf statured wheat cultivars continuously replaced the older tall types at a rate of $2 \mathrm{~m}$ ha year ${ }^{-1}$ in the 1980s (Byerlee and Moya, 1993). There is, however, a growing recognition that dissemination, application, and adoption of this technology have been slower in marginal environments, especially those affected by drought. Over the last three decades, many investigators have attempted to produce wheat cultivars adapted to these semi-arid environments with limited success in earlier years.

To examine the challenges facing wheat breeders more closely, Singh and Byerlee (1990) analysed wheat yield variability in 57 countries over 35 years. Yield variability was measured by calculating coefficients of variation of yield around linear climatic 
trends. The amount and distribution of rainfall was the predominant factor influencing yield variability. Countries in which half the wheat was sown in dryland conditions experienced twice as much variability as countries in which wheat was mostly grown under well-watered conditions. At least $60 \mathrm{~m}$ ha of wheat is grown in marginal rain-fed environments in developing countries. National average yields in these regions range from 0.8 to $1.5 \mathrm{t} \mathrm{ha}^{-1}$, which represents approximately $10-50$ percent of their theoretical irrigated potential (Morris et al., 1991).

In recent years, breeders have been more successful in increasing the adaptation of wheat to dry environments. In developing countries, farmers have traditionally grown landrace cultivars that are well adapted to serious moisture stress conditions. However, these traditional cultivars generally give a poor yield in "good years" when rainfall is more plentiful. Modern cultivars now yield the same as the traditional cultivars in dry years as well as showing a better response to more favorable conditions of moisture and nutrient supply (Osmanzai et al., 1987). Due to their improved yield stability, these modern cultivars are increasingly grown in dry regions, with rates of adoption approaching those in irrigated and high rainfall areas.

Further progress in developing drought tolerant germplasm depends on the efficiency of breeding and phenotyping methodologies. Accurate drought phenotyping implies precise definition of the target environment, choice and characterization of the testing environment, and water stress management and characterization.

\section{METHODOLOGY \\ BREEDING STRATEGY}

Breeding work for drought-prone environments has been largely empirical to date, with grain yield being the primary trait for selection in wheat breeding programmes. However, most breeders select strongly for traits other than yield in the early segregating generations and do yield testing only at later stages, when a certain level of homozygosity has been achieved and large enough seed quantities are available. The decision to advance or reject a genotype is often complex and, in practical terms, breeders most often use a system of multiple cut-offs. In early generations, they select genotypes that, presumably, achieve the levels required for the primary traits evaluated in segregating populations (plant type, plant height, growth cycle, spike fertility, etc.).

When a breeding programme for drought adaptation is assisted by analytical selection, the conceptual model used considers yield under drought to be a function of: (1) yield potential; (2) flowering date (which indicates whether the crop will avoid drought stress); and (3) secondary traits that provide drought resistance. Physiological secondary traits can be used for the selection of parents to be included in the crossing block, as direct selection criteria for screening among a large number of genotypes (i.e., segregating populations) and/or when the amount of seed available is too small to carry out field trials with replications. Whereas intensive work is continuously being carried out by physiologists in the area of drought adaptation, few breeders routinely use physiological criteria in their mainstream breeding programmes. In the first place, the evaluation of some of the traits proposed by plant physiologists is time-consuming or expensive. This is not practical for application to the thousands of entries that comprise the segregating generations of breeding programmes. Then, the real value of a given trait may only be assessed by determining the genetic gain in segregating populations following selection, while many traits are not available in well adapted genotypes and their validation frequently requires the development of appropriate breeding material, which is again costly and time-consuming (Royo et al., 2005). Finally, selection in segregating populations requires screening at the plant level or between very small plots, thus hindering the use of traits that require large field plots for their assessment.

Gene-based markers generated from gene sequence data, i.e., "perfect markers" can be used to screen large numbers of entries for a particular trait improving the efficiency and effectiveness of conventional breeding. Gene-based markers are particularly useful for introgressing genes whose expression is highly affected by the environment, such as genes for useful physiological traits that cannot easily be screened (e.g., root architecture traits), as well as for gene pyramiding. The most common situations in which marker-assisted selection (MAS) confers an advantage are: (1) when accurate measurement of the phenotype is expensive or difficult; (2) when multiple genes conferring a similar phenotype are being combined; and (3) when there is a need for rapid removal of donor chromosome segments in a backcrossing programme (Nelson et al., 2004). Most important traits (yield, stress adaptation, etc.) are governed by multiple genes, each producing a relatively small individual effect. MAS for these "quantitative traits" is challenging because many quantitative trait loci (QTLs) identified in mapping population studies are crossspecific, subject to genotype-by-environment interaction (GEI) effects.

QTL estimation often spans several centimorgans, and hundreds of genes underlie a region of this size. The size of such a region can be reduced through a number of approaches, such as the use of high resolution crosses, or the development of nearisogenic lines (NILs) for small chromosomal segments across the putative QTL region (Nelson et al., 2004). Linkage disequilibrium (LD) mapping offers another alternative, exploiting the long history of recombination, and rich allelic diversity in germplasm collections (Remington et al., 2001; Buckler and Thornsberry, 2002). Genome sequencing for various crops would improve the quality of molecular markers used for MAS by helping breeders to target the gene of interest, rather than a nearby sequence (Dubcovsky, 2004). Continuing efforts to sequence expressed genes will provide data for SNP markers for individual alleles, making MAS more cost-efficient (Dubcovsky, 2004).

For MAS to be useful, proper phenotyping is required and the evaluation of yield and relevant physiological traits should be done in conditions similar those of the target environment. An ecophysiological understanding of the traits in question and of how to measure them is crucial (Araus et al., 2003a,b; Slafer, 2003).

\section{TRIAL PLANNING \\ Definition of the target environment}

Rainfall distribution patterns and evaporative demand over the crop cycle vary considerably among locations and years. 
The different sets of climatic conditions under which wheat is cultivated are characterized by breeders as "wheat megaenvironments" (wheat MEs). ME delineation is based on water availability, soil type, temperature regime, production system, and associated biotic and abiotic stresses. Consumer preferences for grain color and industrial and end-use quality are also considered. CIMMYT has defined 12 MEs (Table 2): six focus on spring wheat production areas, three on facultative wheat areas, and three on true winter wheat areas (Rajaram et al., 1995). According to the ME classification, drought environments mainly correspond to ME4. Within ME4, three distinct patterns can be distinguished: post-anthesis water stress (ME4A); pre-anthesis water stress (ME4B); and residual moisture stress (ME4C). In the first scenario, ME4A, evapotranspiration exceeds average precipitation after anthesis, causing an increasing water deficit over the grain-filling period. Conversely, in ME4B, water deficit occurs mainly before anthesis. In ME4C, there is no significant rainfall, and evaporation is always in excess of precipitation during the growing season. Consequently, the crop must survive using the water stored in the soil profile from the summer rainfall. Wheat can also face drought situations in other MEs, such as ME6B, ME9, and ME12. In all drought situations, wheat may also experience additional stresses such as heat and cold stress, soil micro-element deficiency, or toxicity, and a range of biotic stresses. For example, late frosts frequently occur in ME4A, while high temperature stress occurs in ME5A. In ME4B, resistances to leaf and stem rust, Septoria spp and Fusarium spp, and pre-harvest sprouting are highly necessary.

\section{Choice and characterization of the testing environment}

The choice of the selection environment directly determines the potential genetic gains in the target environment. Ideally, the selection environment should mimic the target environment in all aspects: water distribution, profiles and potential evapotranspiration rates, and physical and chemical soil properties. Deviations may result in significant GEI between target and selection environments, and genetic gains achieved in the selection environment may not be expressed in the target environment.
Geographic information system (GIS) tools can help considerably in describing the relationships between target and selection environments and establishing "homology maps."

The crop facing water deficit simultaneously experiences a number of additional stress factors (e.g., micronutrient deficiency, soil compaction, salinity, nematodes, and fungal pathogens) that exacerbate drought stress. Such factors are hard to control and are generally not considered in field experiments. Hence, efforts should be made to remove all other constraints except drought. Soil surveys may allow the identification of selection sites or fields that avoid confounding factors. In some cases, these surveys may enable sites to be chosen where the selection pressure for these stress factors would permit the selection of genotypes targeted for regions where these stresses interact with drought. They could also identify the within-site distribution of e.g., nematodes (Nicol and Ortiz-Monasterio, 2004) or zinc deficiency (Ekiz et al., 1998). Field trials are conducted on land that may be quite variable in terms of topography, soil fertility, and soil structure. Spatial variability in the field affects the detection of treatment differences in agricultural experiments by inflating the estimated experimental error variance. In order to account for such variation and to reduce experimental error, adapted trial designs must be applied, like the augmented designs proposed by Federer (2005).

\section{WATER STRESS MANAGEMENT AND CHARACTERIZATION}

Target environments can also be mimicked if water is controlled by imposing a water regime by gravity or, better, by drip irrigation. Water stress management (timing, intensity, uniformity) and characterization (soil, plant measurements) are essential issues in drought phenotyping.

Moisture availability can itself be a complicating factor when comparing genotypes in field experiments. Although plots growing the different genotypes may receive the same quantity of water, the genotypes can vary in their water use and/or access to underground water, thereby confounding measurements associated with plant water relations. Study of water profiles (either experimentally or by using simulation models) can provide very

Table 2 | The main wheat mega-environments (Source: Rajaram et al., 1995).

\begin{tabular}{|c|c|c|c|c|c|}
\hline $\mathrm{ME}^{a}$ & Moisture regime & Temperature & Wheat type & Area (\%) & Production ( $10^{6}$ tons) \\
\hline ME1 IR & $\mathrm{IR}$ & Temperate & Spring & 36.1 & 83 \\
\hline ME2 HR & $\mathrm{HR}(>500 \mathrm{~mm})$ & Temperate & Spring & 8.5 & 25 \\
\hline ME3 AS & $\mathrm{HR}(>500 \mathrm{~mm}) ; \mathrm{AS}$ & Temperate & Spring & 1.9 & 3 \\
\hline ME4 SA & $\mathrm{LR}(<500 \mathrm{~mm})$ & Temperate/hot & Spring & 14.6 & 20 \\
\hline ME5 TE & $\mathrm{IR}, \mathrm{HR}$ & Hot & Spring & 7.1 & 12 \\
\hline ME6 HL & SA & Temperate & Spring & 6.2 & 13 \\
\hline ME7 IR & $\mathrm{IR}$ & Cool & Facultative & - & - \\
\hline ME8 HR & $\mathrm{HR}$ & Cool & Facultative & 10.0 & 23 \\
\hline ME9 SA & SA & Cool & Facultative & - & - \\
\hline ME10 IR & IR & Cold & Winter & - & - \\
\hline ME11 HR & $H R$ & Cold & Winter & 15.0 & 30 \\
\hline ME12 SA & SA & Cold & Winter & - & - \\
\hline
\end{tabular}

${ }^{a} M E$, Mega-environment; where: IR, irrigated; HR, high rainfall; $A S$, acid soil; SA, semi-arid; TE, tropical environment; HL, high latitude. 
useful information. Trait evaluation should preferably be carried out under field conditions, avoiding experimental situations (growth chambers, greenhouses, pots) that differ significantly from the agricultural growing environment. The ability to access water deep in the soil profile, which is an important droughtadaptive mechanism, is eliminated as a variable in pot conditions. Furthermore, the relative humidity of the air, which has an important influence on stomatal conductance (Ben Haj Salah and Tardieu, 1997), is extremely difficult to simulate in controlled environments.

When possible, drought tolerance evaluation should be done out-of-season, under irrigated conditions. This option allows better management of water stress but needs a dry season sufficiently long to cover the whole growth cycle. The photoperiod and temperature should not differ too much from the growing season, as is the case in the dry tropics, to avoid genotype-by-season interactions and allow results obtained from the out-of-season experiments to be extrapolated to the growing season conditions.

\section{PLANT WATER STRATEGY}

\section{Survival and drought escape}

In the case of drought, some traits proposed by stress physiologists appear to be associated with crop survival. For example, comparison of old and new varieties has shown that, under drought, older varieties over-produce tillers many of which fail to set grain, while modern drought tolerant lines produce fewer tillers the majority of which survive (Loss and Siddique, 1994). In most circumstances, however, the main effect of drought is to reduce grain yield without killing the plant.

If the pattern of water deficit is predictable in a given region, selection for a flowering date that does not coincide with the period of water deficit is a very effective way of improving drought adaptation (Araus et al., 2002). The limitations of this approach are that very early varieties may suffer yield penalties in good seasons, while late-in-season freezing episodes may affect spike fertility. In such cases, breeding for higher yield potential plus traits conferring stress avoidance (i.e., to avoid cell dehydration) may generally be effective (Araus et al., 2003a,b).

\section{PHENOTYPING TRAITS Requirements}

Most of the traits currently mentioned in the literature associated with drought adaptation in wheat are shown in Table 3. However, the potential value of each trait needs to be considered with respect to the type of drought environment in which a cultivar is to be adapted. Secondary traits may be particularly suited to improving the selection response for stress conditions if they avoid any confounding effects of stress timing on yield (e.g., drought and flowering dates), and allow the selection to be focused on a specific type of drought. For a secondary trait to be useful in a breeding programme, it has also to comply with several requirements (Edmeades et al., 1997). Thus, a secondary trait should ideally be: (1) genetically associated with grain yield under drought; (2) genetically variable; (3) highly heritable; (4) easy, inexpensive and fast to observe or measure; (5) non-destructive; (6) stable over the measurement period; and (7) not associated with yield loss under unstressed conditions.
Wheat faces different drought scenarios worldwide; consequently, the physiological traits that confer drought resistance in specific environments may be very distinct. The combination of yield data with data relating to secondary traits in multi-site field experiments ranging from well-watered to high stress levels may be useful at this stage by providing some light on GEI of traits related to drought tolerance. This is particularly the case when the heritability of the secondary traits is higher than that of yield, and the genetic correlation of these traits with yield in the target environment is high. Secondary traits can be classified according to their relationship to pre-anthesis growth, access to water, water-use efficiency (WUE), and photoprotection.

\section{Traits related to pre-anthesis growth}

Crop establishment. Vigorous crop establishment is agronomically desirable because it helps to shade the soil and suppress weeds that compete for water. It also improves radiation interception by the crop at the early stages of growth. Rapid ground cover can be achieved by breeding for: (1) large seed and embryo size which may help to achieve early vigor (Aparicio et al., 2002); and (2) thinner, wider leaves (i.e., with a relatively low specific leaf weight) and a more prostrate growth habit which help to increase ground cover, thus conserving soil moisture and potentially increasing radiation-use efficiency (RUE; Richards, 1996). These traits are especially important in Mediterranean types of drought environment (ME4A), where up to 40 percent of available water may be lost by evaporation directly from the soil (Loss and Siddique, 1994). In ME4A, the potential for vigorous growth prior to heading also provides the opportunity to take advantage of relatively good growing temperatures and moisture availability earlier in the cycle.

Total biomass. Evaluation of total biomass is only feasible in practice through indirect methods, e.g., using spectroradiometers to measure the spectra of light reflected by the canopy (Aparicio et al., 2000, 2002; Royo et al., 2003). Field spectroradiometers able to measure the spectrum of light reflected by the canopy have been expensive in the past. However, the situation is now changing with the availability of simple, less expensive, and easyto-handle spectroradiometers such as the GreenSeeker ${ }^{1}$. Designed initially for nitrogen management, this has become a potentially very useful instrument in breeding. It gives the basic spectroradiometric indices of green biomass, such as the normalized difference vegetation index (NDVI), which is the most useful for routine breeding purposes. Moreover, as the GreenSeeker includes its own radiation source, it may be used independently of atmospheric conditions and deployed on both sunny and cloudy days. Alternative techniques such as the use of an affordable conventional digital camera may provide complementary information, such as the portion of the soil occupied by green biomass (Casadesús et al., 2005). Digital pictures may also provide information that is not currently acquired through spectral reflectance measurements, such as the degree of soil covered by the crop, the percentage of yellow leaves, or even yield components such as the number of spikes per unit land area (Casadesús et al., 2005).

\footnotetext{
${ }^{1}$ http://www.ntechindustries.com/
} 
Table 3 | Main secondary traits that can be used to improve drought tolerance in wheat, associated mechanisms, references, ease of use, and target mega-environment of application (Adapted from Reynolds et al., 2001b).

\begin{tabular}{|c|c|c|c|c|}
\hline $\begin{array}{l}\text { Secondary } \\
\text { trait }\end{array}$ & $\begin{array}{l}\text { Associated } \\
\text { with }\end{array}$ & $\begin{array}{l}\text { Methodology } \\
\text { (References) }\end{array}$ & $\begin{array}{l}\text { Ease } \\
\text { of use }\end{array}$ & $\begin{array}{l}\text { Target } \\
\text { environment }\end{array}$ \\
\hline Large seed size & $\begin{array}{l}\text { Emergence, early ground cover, and } \\
\text { initial biomass }\end{array}$ & Mian and Nafziger, 1994 & +++ & ME4A \\
\hline Long coleoptiles & Emergence from deep sowing & Radford, 1987 & +++ & ME4C \\
\hline Early ground cover (visual) & $\begin{array}{l}\text { Decrease of evaporation and } \\
\text { increase of radiation-use efficiency } \\
\text { (RUE) }\end{array}$ & Hafid et al., 1998; Richards, 1996 & +++ & ME4A \\
\hline Specific leaf dry weight & $\begin{array}{l}\text { Thinner, wider leaves, early ground } \\
\text { cover }\end{array}$ & Merah et al., 2001a & ++ & ME4A \\
\hline Growth habit (visual) & $\begin{array}{l}\text { Lower soil evaporation and higher } \\
\text { RUE }\end{array}$ & Richards et al., 2002 & +++ & ME4A \\
\hline Tiller survival & Survival and recovery & Loss and Siddique, 1994 & ++ & Severe stress \\
\hline Long and thick stem internodes & Storage of carbon products & Loss and Siddique, 1994 & +++ & ME4A \\
\hline $\begin{array}{l}\text { Vegetation indices (normalized } \\
\text { difference vegetation index; NDVI) }\end{array}$ & Green biomass & Royo et al., 2003 & + & \\
\hline Earliness & Drought escape & $\begin{array}{l}\text { Blum, 1988; Monneveux et al., } \\
2005\end{array}$ & +++ & ME4A and ME4C \\
\hline Number of grain per spike around & Spike sterility & Hafsi et al., 2006 & ++ & Drought flowering \\
\hline Stomatal conductance & Extraction of water from soil & Farquhar and Sharkey, 1982 & + & \\
\hline Canopy temperature depression & $\begin{array}{l}\text { Stomatal conductance, extraction } \\
\text { of water from soil }\end{array}$ & Reynolds et al., 2000 & ++ & \\
\hline Carbon isotope discrimination & $\begin{array}{l}\text { Stomatal conductance, extraction } \\
\text { of water from soil }\end{array}$ & Monneveux et al., 2005 & ++ & \\
\hline Ash content & $\begin{array}{l}\text { Stomatal conductance, extraction } \\
\text { of water from soil }\end{array}$ & Misra et al., 2006 & ++ & \\
\hline Spike photosynthetic capacity & Grain filling & Evans et al., 1972 & + & ME4A, hot \\
\hline Leaf color (visual, SPAD) & $\begin{array}{l}\text { Delayed senescence, maintenance } \\
\text { of photosynthesis }\end{array}$ & Araus et al., 1997 & +++ & \\
\hline Leaf waxiness & $\begin{array}{l}\text { Lower transpiration rate and } \\
\text { reduced photo-inhibition }\end{array}$ & Richards, 1996 & +++ & Severe stress \\
\hline Leaf pubescence & $\begin{array}{l}\text { Lower transpiration rate and } \\
\text { reduced photo-inhibition }\end{array}$ & Richards, 1996 & +++ & Severe stress \\
\hline Leaf thickness and posture & $\begin{array}{l}\text { Lower transpiration rate and } \\
\text { reduced photo-inhibition }\end{array}$ & Reynolds et al., 2000 & +++ & Severe stress \\
\hline Leaf rolling & $\begin{array}{l}\text { Lower transpiration rate and } \\
\text { reduced photo-inhibition }\end{array}$ & Reynolds et al., 2001b & +++ & Severe stress \\
\hline Glume pubescence & $\begin{array}{l}\text { Lower transpiration rate and } \\
\text { reduced photo-inhibition }\end{array}$ & Trethowan et al., 1998 & +++ & \\
\hline Delayed senescence & Higher RUE & Hafsi et al., 2006 & ++ & \\
\hline Fructanes in stem & Storage of carbon products & Rawson and Evans, 1971 & ++ & ME4A \\
\hline Solute concentration in cells & Osmotic adjustment (OA) & Morgan and Condon, 1986 & + & \\
\hline Accumulation of ABA & $\begin{array}{l}\text { Reduced stomatal conductance and } \\
\text { cell division }\end{array}$ & Innes et al., 1984 & + & Severe stress \\
\hline
\end{tabular}

Remobilization of stored assimilates. Stored assimilates can be remobilized during grain filling to supplement assimilates generated in the drier post-anthesis period. Stored fructans contribute substantially to grain filling, especially when canopy photosynthesis is inhibited by post-anthesis drought (Blum, 1998). Traits that may also contribute to remobilization during grain filling in these conditions include long and thick stem internodes, perhaps with extra storage tissue in the form of solid stems. In studies where crosses were made between lines contrasting in the solid-stem trait, the solid-stem progeny contained more soluble carbohydrate per unit of stem length, although total stem carbohydrate was unaffected due to the stems being narrower and shorter (Ford et al., 1979). Conversely, where the crop grows exclusively on stored soil moisture, long coleoptiles are desirable to avoid extremely hot soil surface temperatures and rapid soil drying. Moreover, longer coleoptiles improve seedling emergence with deep sowing (Radford, 1987), improving early biomass accumulation (Rebetzke et al., 
2005). Long coleoptiles are also useful in dryland Mediterranean environments, helping to avoid a false start in early planted crops.

\section{Traits relating to access to water}

Root characteristics. A root system that can extract whatever water is available in the soil profile is clearly drought-adaptive (Hurd, 1968), but this ability is difficult to measure directly. Traits that are indicative of the water status of a plant, especially when measured during periods of peak stress, are useful indicators of the plant's capacity to match evaporative demand by exploring and extracting soil water. Instantaneous measurement of traits affected by the water relations of the plant, such as stomatal conductance $\left(g_{s}\right)$ and canopy temperature depression (CTD) can give indications of water extraction patterns. The role of abscisic acid (ABA) accumulation in stomatal regulation under drought has been demonstrated (Innes et al., 1984). It also appears to preadapt plants to stress by reducing rates of cell division, reducing organ size, and increasing the rate of development. However, high ABA can also result in sterility problems since high ABA levels may abort developing florets.

Canopy temperature depression. Among the traits relating to access to water, by far the easiest to measure in the field is CTD, which shows good correlations with other water relations parameters (Blum et al., 1982), as well as with performance under drought of random sister lines (Reynolds et al., 2000). Canopy temperature can provide information on transpiration as the main contributor to reduced leaf temperature. Although canopy temperature may seem very easy to measure, in practice there are methodological problems, particularly in Mediterranean drought environments. This is mainly found when there is variation in the air temperature with wind or cloudiness (Araus et al., 2002; Royo et al., 2002), or where there is not a homogeneous canopy. In fact, screening by canopy temperature measurements under drought stress can be done only during the vegetative growth stage after full ground cover has been attained, before inflorescence emergence, at high vapour-pressure deficits in recently irrigated crops, and without the presence of wind or clouds (Royo et al., 2005).

So far, studies have only been accomplished in recombinant inbred lines (RILs). CTD showed a significant association with yield under drought when measured pre-anthesis, suggesting an advantage from higher pre-anthesis growth rates. CTD also showed some association with final yield when measured during grain filling. Because a major role of transpiration is leaf cooling, canopy temperature, and its reduction relative to ambient air temperature are an indication of how much transpiration cools the leaves under a demanding environmental load. Higher transpiration means colder leaves and higher stomatal conductance, both aspects favoring net photosynthesis and crop duration. A relatively lower canopy temperature in drought-stressed crops indicates a relatively greater capacity for taking up soil moisture or for maintaining a better plant water status. Thus, higher transpiration is a positive trait when selecting for higher yield potential or better adaptation to moderate drought stress.
Osmotic adjustment. Solute concentration in the cell is intimately tied to plant water status and, under drought, osmotic adjustment (OA) may facilitate critical growth functions such as root growth, and also meiosis and pollen development, thereby mitigating some of the most detrimental effects of plant water deficit. Genetic variation in $\mathrm{OA}$ is well-established in wheat (Rekika et al., 1998). A number of experiments have shown that wheat lines selected for high OA in response to the lowering of leaf water potential have higher grain yields in field experiments. In a study by Morgan and Condon (1986), high OA was strongly associated with greater soil water extraction. Nevertheless, the role of OA on yield still remains controversial (Serraj and Sinclair, 2002). It will help to maintain leaf metabolism and root growth at relatively low leaf water potentials by maintaining turgor pressure in cells. However, OA is difficult to measure in large samples under field conditions. Some research suggests that the trait can be assayed relatively easily by measuring the coleoptile growth rate of seedlings in a polyethylene glycol (PEG) solution (Morgan, 1988).

Carbon isotope discrimination. Carbon isotope discrimination $\left(\Delta^{13} \mathrm{C}\right)$, despite being a very promising trait, is probably less widely accepted because of the cost of its determination. In recent years, Commonwealth Scientific and Industrial Research Organisation (CSIRO, Australia) Plant Industry has released the first two commercial wheat varieties selected for high transpiration efficiency using $\Delta^{13} \mathrm{C}$ ("Drysdale" in 2002, and "Rees" in 2003). These varieties are cultivated under rain-fed conditions and rely solely upon the precipitation accumulated prior to planting. They have been selected based on their low $\Delta^{13} \mathrm{C}$ (and thus high transpiration efficiency), fitting with what has been postulated with regard to this trait. However, for Mediterranean environments, $\Delta^{13} \mathrm{C}$ (particularly when measured in mature grains) is frequently positively correlated with grain yield (Araus et al., 1998; Villegas et al., 2000; Merah et al., 2001b; Condon et al., 2004; Monneveux et al., 2005). One of the reasons for this positive relationship is that a genotype exhibiting higher $\Delta^{13} \mathrm{C}$ is probably able to maintain a better water status (Condon et al., 2004). Given the relatively high costs associated with carbon isotopic analysis (about $€ 10$ per sample), several surrogate approaches which are much cheaper, faster, and easier to handle have been proposed. The option most studied has been to use the mineral or ash content of leaves (Masle et al., 1992; Mayland et al., 1993; Araus et al., 1998; Merah et al., 1999) or grains (Febrero et al., 1994; Voltas et al., 1998; Monneveux et al., 2005; Misra et al., 2006). Another promising alternative relies on the estimation of $\Delta^{13} \mathrm{C}$ through the near-infrared spectroscopy (NIRS) technique (Clark et al., 1995; Ferrio et al., 2001), which carries with it the further advantage of being non-destructive.

\section{Traits relating to water-use efficiency}

Measurement of carbon isotope discrimination or ash content of grain or other tissues can be used to estimate the WUE of the crop, since their signals are based on the integration of plant water status over a period of time (Condon et al., 1993). However, these data must be interpreted with care. Although most field 
studies have shown that better performance of wheat cultivars under Mediterranean drought conditions is associated with lower WUE (Condon et al., 1993), studies in Australia (Rebetzke et al., 2002) indicated an advantage for high WUE genotypes under conditions where crops survive exclusively on stored soil moisture.

Spikes have higher WUE than leaves, and have been shown to contribute up to 40 percent of total carbon fixation under moisture stress (Evans et al., 1972). Awns contribute substantially to spike photosynthesis and longer awns are a possible selection criterion. While gas exchange measurement of spikes is time consuming and difficult to standardize, chlorophyll fluorescence should be considered as a more rapid means of screening for spike photosynthetic capacity under stress (Horton, pers. communication).

Genes that affect a greater relative partitioning of assimilates to the sink, resulting in a higher $\mathrm{HI}$, would be expected to improve yield under drought, not being associated with the water cost of generating additional biomass. Plant height is usually negatively related with $\mathrm{HI}$. However, there is a minimum height below which limitation on yield becomes evident (Slafer et al., 2005). Under extreme drought stress where most of the canopy may have senesced, spike photosynthesis can play a major role in grain filling, because of high WUE of the spike due to the fact than they can refix respiratory carbon (Bort et al., 1996). Moreover, they are able to maintain a better water status than leaves, through a higher OA and a more xeromorphic structure (Tambussi et al., 2005). This stay-green spike trait is currently being introgressed by CIMMYT into elite drought-tolerant backgrounds to see if it can be combined with yield responsiveness, such that the trait is facultative, responding only in drier years. Changes in leaf color can reflect a variation in partitioning of assimilates to the sink. Stress may accelerate the senescence of leaves. The stay-green trait may indicate the presence of drought avoidance mechanisms, but probably does not contribute to yield per se if there is no water left in the soil profile by the end of the cycle to support leaf gas exchange. It may be detrimental if it indicates lack of ability to remobilize stem reserves (Blum, 1998).

To check for delayed senescence of leaves, particularly flag leaves, portable chlorophyll meters such as the Minolta SPAD ${ }^{2}$ are extensively used, due to their speed and ease of use. Delayed senescence of leaves has been proposed as a secondary trait for performance under drought by several authors (Araus et al., 1997; Rharrabti et al., 2001). However, the relationship between delayed senescence and yield has been found by other authors to be unstable and highly dependent on drought intensity (Hafsi et al., 2006). In addition, the cost of a portable chlorophyll meter makes this device unaffordable for many breeding programmes in developing countries.

\section{Traits relating to photoprotection}

Decreased stomatal conductance in response to drought leads to warmer leaf temperatures and insufficient $\mathrm{CO}_{2}$ to dissipate

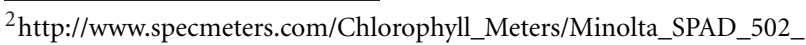
Meter.html
}

incident radiation, both of which increase the accumulation of harmful oxygen radicals and photo-inhibitory damage. Photoinhibition can be modified by some leaf adaptive traits such as waxiness, pubescence, rolling, thickness, or posture (Richards, 1996). These traits decrease the radiation load to the leaf surface. Benefits include a lower evapotranspiration rate and reduced risk of irreversible photo-inhibition. However, they may also be associated with reduce RUE, which would reduce yield under more favorable conditions.

The effects of photo-inhibition can be alleviated by antioxidants such as superoxide dismutase (SOD) and ascorbate peroxidise, which have been shown to increase in quantity in response to drought stress (Mittler and Zilinskas, 1994). Thermal dissipation through the xanthophyll cycle is another protective mechanism that can dissipate as much as 75 percent of absorbed light energy (Niyogi, 1999). In a study comparing a droughtadapted barley landrace with a modern cultivar, the former displayed two mechanisms of photoprotection: (1) rapid xanthophyll cycling; and (2) up to 50 percent less leaf chlorophyll, resulting in a passive reduction of light absorbance (Havaux and Tardy, 1999).

\section{Application in breeding}

While many traits have been studied for their use in breeding for drought resistance, there is a general consensus among breeders that only a few of them can be recommended for use in practical breeding programmes at this time (Table 3). For example, CIMMYT (Reynolds et al., 2001a) recommend the use of flowering and maturity dates, spike fertility, changes in green biomass (e.g., leaf death score), and canopy temperature. In practical terms, these traits seem valuable when breeding for higher yield potential and adaptation to some degree of stress. Development of new equipment like spectroradiometers will facilitate future measurement of new physiological traits in the field. Most other traits cannot yet be recommended as part of an ongoing breeding programme, particularly those that are expensive or difficult to measure. However, some such as $\Delta^{13} \mathrm{C}$ can be used for the selection of parents (Misra et al., 2006; Xu et al., 2007). Thermal imaging and color imaging techniques are expected to greatly facilitate large scale evaluations in the next future (Cabrera-Bosquet et al., 2012).

\section{CONCLUSIONS}

Many drought-adaptive traits have been investigated in wheat. However, association of these traits with genetic gains for yield under drought has been poorly tested and documented. Most difficulties encountered in the identification of accurate drought tolerance traits are due to the fact that wheat is cultivated under very different climatic conditions and faces very different drought scenarios worldwide.

While some single traits have benefited from tremendous research efforts and have generated considerable debate in the literature (e.g., OA, ABA), relatively little emphasis has been placed on research that can be extrapolated and used directly to crop genetic improvement in target environments.

Most drought physiology research in wheat has been conducted in controlled environments and has been poorly 
integrated into breeding programmes. Multidisciplinary approaches involving physiologist, breeders, genebank managers, and biotechnologists are still scarce, holding back the exploitation of genetic diversity and the use of MAS for drought tolerance improvement.

\section{REFERENCES}

Aparicio, N., Villegas, D., Araus, J. L., Blanco, R., and Royo, C. (2002). Seedling development and biomass as affected by seed size and morphology in durum wheat. J. Agric. Sci. 139, 143-150.

Aparicio, N., Villegas, D., Casadesús, J., Araus, J. L., and Royo, C. (2000). Spectral reflectance indices for assessing durum wheat biomass, green area, and yield under Mediterranean conditions. Agron. J. 92, 83-91.

Araus, J. L., Amaro, T., Casadesús, J., Asbati, A., and Nachit, M. M. (1998). Relationships between ash content, carbon isotope discrimination and yield in durum wheat. Aust. J. Plant Physiol. 25, 835-842.

Araus, J. L., Amaro, T., Zuhair, Y., and Nachit, M. M. (1997). Effect of leaf structure and water status on carbon isotope discrimination in field-grown durum wheat. Plant Cell Environ. 20, 1484-1494.

Araus, J. L., Bort, J., Steduto, P., Villegas, D., and Royo, C. (2003a). Breeding cereals for Mediterranean conditions: ecophysiological clues for biotechnology application. Ann. Appl. Biol. 142, 129-141.

Araus, J. L., Villegas, D., Aparicio, N., García Del Moral, L. F., El Hani, S., Rharrabti, Y., et al. (2003b). Environmental factors determining carbon isotope discrimination and yield in durum wheat under Mediterranean conditions. Crop Sci. 43, 170-180.

Araus, J. L., Slafer, G. A., Reynolds, M. P., and Royo, C. (2002). Plant breeding and water relations in $\mathrm{C}_{3}$ cereals: what should we breed for? Ann. Bot. 89, 925-940.

Ben Haj Salah, H., and Tardieu, F. (1997). Control of leaf expansion rate of droughted maize plants under fluctuating evaporative demand. A superposition of hydraulic and chemical messages? Plant Physiol. 114, 893-900.

Blum, A. (1988). Plant Breeding for Stress Environments. Boca Raton, FL: CRC Press.

Blum, A. (1998). Improving wheat grain filling under stress by stem reserve mobilisation. Euphytica 100, 77-83.

Blum, A., Mayer, J., and Gozlan, G. (1982). Infrared thermal sensing of plant canopies as a screening techwheat. Field Crops Res. 5, 137-146.

Borras, L., Slafer, G. A., and Otegui, M. E. (2004). Seed dry weight response to source-sink manipulations in wheat, maize and soybean: a quantitative reappraisal. Field Crops Res. 86, 131-146.

Bort, J., Brown, R. H., and Araus, J. $\mathrm{CO}_{2}$ in the ears of $\mathrm{C}_{3}$ cereals. J. Exp. Bot. 47, 1567-1575.

Brancourt-Hulmel, M., Doussinault, G., Lecomte, C., Bérard, P., Le Buanec, B., and Trottet, M. (2003). Genetic improvement of agronomic traits of winter wheat cultivars released in France from 1946 to 1992. Crop Sci. 43, 37-45.

Briggle, L. W., and Curtis, B. C. (1987). "Wheat worldwide," in Wheat and Wheat Improvement, ed E. G. Heyne (Madison, WI: American Society of Agronomy ), 4-31.

Buckler, E. S., and Thornsberry, J. M. (2002). Plant molecular diversity and applications to genomics. Curr. Opin. Plant Biol. 5, 107-111.

Byerlee, D., and Moya, P. (1993). Impacts of International Wheat Breeding Research in the Developing World, 1966-1990. Mexico: CIMMYT, 73.

Cabrera-Bosquet, L., Crossa, J., von Zitzewitz, J., Serret, M. D., and Araus, J. L. (2012). Highgenomic selection: the frontiers of crop breeding converge. J. Integr. Plant Biol. 54, 312-320.

Calderini, D. F., Reynolds, M. P., and Slafer, G. A. (1999). "Genetic gains in wheat yield and associated physiological changes during the twentieth century," in Wheat: Ecology and Physiology of Yield Determination, eds E. H. Satorre and G. A. Slafer (Binghamton, NY: Haworth Press), 351-377.

Casadesús, J., Biel, C., and Savé, R. (2005). "Turf color measurement with conventional digital cameras," in EFITA/WCCA Joint Congress in Agriculture, eds J. Boaventura Cunha and R. Morais (Vila Real: Universidade de Trás-os-Montes e Alto Douro), 804-811.

Clark, D. H., Johnson, D. A., Kephart, K. D., and Jackson, N. A. (1995). Near infrared reflectance nique for dehydration avoidance in L. (1996). Refixation of respiratory throughput phenotyping and

Despite the tremendous potential offered by access to genetic resources from related species, and well-documented success in using them (e.g., $1 \mathrm{~B} / 1 \mathrm{R}$ translocation, synthetic wheats), wild Triticeae have been poorly exploited until now to improve drought tolerance in wheat.

spectroscopy estimation of ${ }^{13} \mathrm{C}$ discrimination in forages. J. Range Manage. 48, 132-136.

Condon, A. G., Richards, R. A., and Farquhar, G. D. (1993). Relationships between carbon isotope discrimination, water use efficiency and transpiration efficiency for dryland wheat. Aust. J. Agric. Res. 44, 1693-1711.

Condon, A. G., Richards, R. A. Rebetzke, G. J., and Farquhar, G. D. (2004). Breeding for high water-use efficiency. J. Exp. Bot. 55, 2447-2460.

Donmez, E., Sears, R. G., Shroyer, J. P., and Paulsen, G. M. (2001). Genetic gain in yield attributes of winter wheat in the Great Plains. Crop Sci. $41,1412-1419$.

Dubcovsky, J. (2004). Marker-assisted selection in public breeding programs: the wheat experience. Crop Sci. 44, 1895-1898.

Edmeades, G. O., Bolaños, J., and Chapman, S. C. (1997). "Value of secondary traits in selecting for drought tolerance in tropical maize," in Developing Drought and Low-N Tolerant Maize, eds G. O. Edmeades, M. Banziger, H. R. Nickelson, and C. B. Peña-Valdivia (Mexico: CIMMYT), 222-234.

Ekiz, H., Bagci, S. A., Kiral, A. S., Eker, S., Gültekin, I., Alkan, A., et al. (1998). Effects of zinc fertilization and irrigation on grain yield and zinc concentration of various cereals grown in zinc-deficient calcareous soils. J. Plant Nutr. 21, 2245-2256.

Evans, L. T., Bingham, J., Johnson, P., and Sutherlands, J. (1972). Effect of awns and drought on the supply of photosynthate and its distribution within wheat ears. Ann. Appl. Biol. 70, 67-76.

FAO. (2007). FAOSTAT. FAO Statistical Databases. Available online at: http://faostat.fao.org/

Farquhar, G. D., and Sharkey, T. D. (1982). Stomatal conductance and photosynthesis. Annu. Rev. Plant Physiol. 33, 317-345.

Febrero, A., Bort, J., Voltas, J., and Araus, J. L. (1994). Grain yield, carbon isotope discrimination and mineral content in mature kernels of barley, under irrigated and rainfed conditions. Agronomie 2, 127-132.
Federer, W. T. (2005). Augmented split plot experimental design. J. Crop Improv. 15, 81-96.

Ferrio, J. P., Bertran, E., Nachit, M. M., Royo, C., and Araus, J. L. (2001). Near infrared reflectance spectroscopy as a new surrogate analysis for $\mathrm{D}^{13} \mathrm{C}$ in mature kernels of durum wheat. Aust. J. Agric. Res. 52, 809-816.

Flintham, J. E., Borner, A., Worland, A. J., and Gale, M. D. (1997). Optimising wheat grain yield: effects of Rht (gibberellininsensitive) dwarfing genes. J. Agric. Sci. 128, 11-25.

Ford, M. A., Blackwell, R. D., Parker, M. L., and Austin, R. B. (1979). Associations between stem solidity, soluble carbohydrate accumulation and other characters in wheat. Ann. Bot. 44, 731-738.

Frankel, O. H. (1975). "Genetic resources centres - a cooperative global network," in Crop Genetic Resources for Today and Tomorrow, eds O. H. Frankel and J. G. Hawkes (UK: Cambridge University Press), 473-481.

Gupta, A. K. (2004). Origin of agriculture and domestication of plants and animals linked to early Holocene climate amelioration. Curr. Sci. 87, 54-59.

Gustafson, J. P., McGuire, P. E., and Qualset, C. O. (2004). Genomic resources: moving wheat into the mainstream in plant genomics. Genetics 168, 583-584.

Hafid, R. E., Smith, D. H., Karrou, M., and Samir, K. (1998). Morphological attributes associated with early-season drought tolerance in spring durum wheat in a Mediterranean environment. Euphytica 101, 273-282.

Hafsi, M., Akhter, J., and Monneveux, P. (2006). Leaf senescence and carbon isotope discrimination in durum wheat (Triticum durum Desf) under severe drought conditions. Cereal Res. Commun. 35, 71-80.

Havaux, M., and Tardy, F. (1999). Loss of chlorophyll with limited reduction of photosynthesis as an adaptive response of Syrian barley landraces to high-light and heat stress. Aust. J. Plant Physiol. 26, 569-578.

Hurd, E. A. (1968). Growth of roots of seven varieties of spring wheat at 
high and low moisture levels. Agron. J. 60, 201-205.

Innes, P., Blackwell, R. D., and Quarrie, S. A. (1984). Some effects of genetic variation in drought-induced abscisic acid accumulation on the yield and water-use of spring wheat. J. Agric. Sci. 102, 341-346.

Jiang, G. M., Sun, J. Z., Liu, H. Q., Qu, C. M., Wang, K. J., Guo, R. J., et al. (2003). Changes in the rate of photosynthesis accompanying the yield increase in wheat cultivars released in the past 50 years. J. Plant Res. 116, 347-354.

Kihara, H. (1919). Über cytolosgische studien bei einigen getreidearten. I. Spezies-bastarde des weizens und weizenmggen-bastarde. Botan. Mag. (Tokyo) 33, 17-38.

Kimber, G., and Sears, E. R. (1987). "Evolution in the genus Triticum and the origin of cultivated wheat," in Wheat and Wheat Improvement, ed E. G. Heyne (Madison, WI: American Society of Agronomy), 154-164.

Loss, S. P., and Siddique, K. H. M. (1994). Morphological and physiological traits associated with wheat yield increases in Mediterranean environments. Adv. Agron. 52, 229-276.

Masle, J., Farquhar, G. D., and Wong, S. C. (1992). Transpiration ratio and plant mineral content are related among genotypes of a range of species. Aust. J. Plant Physiol. 19, 709-721.

Mayland, H. F., Johnson, D. A., Asay, K. H., and Read, J. J. (1993). Ash, carbon isotope discrimination and silicon as estimators of transpiration efficiency in crested wheatgrass. Aust. J. Plant Physiol. 20, 361-369.

McGuire, P. E., and Qualset, C. O. (1997). "Progress in genome mapping of wheat and related species," Joint Proceedings of the 5th and 6th Public Workshops of the International Triticeae Mapping Initiative, 1-3 September 1995, Norwich UK and 30-31 August 1996, Sydney, Australia. Genetic Resources Conservation Program Report No. 18. (University of California Genetic Resources Conservation Program, Davis, California, USA), 195

Merah, O., Deléens, E., and Monneveux, P. (1999). Grain yield, carbon isotope discrimination, mineral and silicon content in durum wheat under different precipitation regimes. Physiol. Plantarum 107, 387-394.

Merah, O., Deléens, E., and Monneveux, P. (2001a). Relationships between flag leaf carbon isotope discrimination and several morphophysiological traits in durum wheat under Mediterranean conditions. Environ. Exp. Bot. 45, 63-71.

Merah, O., Deléens, E., Souyris, I. Nachit, M. M., and Monneveux P. (2001b). Stability of carbon isotope discrimination and grain yield in durum wheat. Crop Sci. 41, 677-681.

Mian, M. A. R., and Nafziger, E. D. (1994). Seed size and water potentia effects on germination and seedling growth of winter wheat. Crop Sci. 34, 169-171.

Misra, S. C., Randive, R., Rao, V. S. Sheshshayee, M. S., Serraj, R., and Monneveux, P. (2006). Relationship between carbon isotope discrimination, ash content and grain yield in wheat in the Peninsular Zone of India. J. Agron. Crop Sci. 192, 352-362.

Mittler, R., and Zilinskas, B. A. (1994). Regulation of pea cytosolic ascorbate peroxidase and other antioxidant enzymes during the progression of drought stress and following recovery from drought. Plant J. 5, 397-405.

Monneveux, P., Reynolds, M. P., Gonzalez, J., and Singh, R. P. (2003). Effects of 7DL.7Ag translocation from Lophopyrum elongatum on wheat yield and related morphophysiological traits under different environments. Plant Breed. 122, 379-384.

Monneveux, P., Reynolds, M. P., Trethowan, R., González-Santoyo, H., Peña, R. J., and Zapata, F. (2005). Relationship between grain yield and carbon isotope discrimination in bread wheat under four water regimes. Eur. J. Agron. 22, 231-242.

Morgan, J. M. (1988). The use of coleoptile responses to water stress to differentiate wheat genotypes for osmoregulation, growth and yield. Ann. Bot. 62 193-198.

Morgan, J. M., and Condon, A. G. (1986). Water use, grain yield and osmoregulation in wheat. Aust. J. Plant Physiol. 13, 523-532.

Morris, M. L., Belaid, A., and Byerlee, D. (1991). "Wheat and barley production in rainfed marginal environments of the developing world," in 1990-1991 CIMMYT World Wheat Factors and Trends (Mexico: CIMMYT), 1-28.

Nelson, R. J., Naylor, R. L., and Jahn, M. M. (2004). The role of genomics research in improvement of "orphan" crops. Crop Sci. 44, 1901-1904.
Nicol, J., and Ortiz-Monasterio, I. (2004). Effects of the root-lesion nematode, Pratylenchus thornei, on wheat yields in Mexico. Nematology 6, 485-493.

Niyogi, K. K. (1999). Photoprotection revisited: genetic and molecular approaches. Annu. Rev. Plant Physiol. Plant Mol. Biol. 50, 333-359.

Osmanzai, M., Rajaram, S., and Knapp E. B. (1987). "Breeding for moisture stressed areas," in Drought Tolerance in Winter Cereals, eds J. P. Srivastava, E. Porceddu, E. Acevedo, and S. Varma (Chichester: John Wiley and Sons), 151-162.

Pasternak, R. (1998). "Investigations of botanical remains from Neval Cori PPNB, Turkey: a short interim report," in The Origins of Agriculture and Crop Domestication, eds A. B. Damania, J. Valkoun, G. Willcox, and C. O. Qualset [Aleppo: International Center for Agricultural Research in the Dry Areas (ICARDA)], 170-176.

Qi, L. L., Echalier, B., Friebe, B., and Gill, B. S. (2003). Molecular characterization of a set of wheat deletion stocks for use in chromosome bin mapping of ESTs. Funct. Integr. Genomics 3, 39-55.

Radford, B. J. (1987). Effect of constant and fluctuating temperature regimes and seed source on the coleoptile length of tall and semidwarf wheats. Aust. J. Exp. Agric. 27, 113-117.

Rajaram, S., van Ginkel, M., and Fischer, R. A. (1995). "CIMMYT's wheat breeding mega-environments (ME)," in Proceedings of the 8th International Wheat Genetics Symposium, eds Z. S. Li and Z. Y. Xin (China Agricultural Scientech Press, Beijing, China), 1101-1106.

Rawson, H. M., and Evans, L. T. (1971) The contribution of stem reserves to grain development in a range of wheat cultivars of different height. Aust. J. Agric. Res. 22, 851-863.

Rebetzke, G. J., Bruce, S. E., and Kirkegaard, J. A. (2005). Longer coleoptiles improve emergence through crop residues to increase seedling number and biomass in wheat (Triticum aestivum L). Plant Soil 272, 87-100.

Rebetzke, G. J., Condon, A. G. Richards, R. A., and Farquhar, G. D. (2002). Selection for reduced carbon isotope discrimination increases aerial biomass and grain yield of rainfed bread wheat. Crop Sci. 42, 739-745.

Rekika, D., Nachit, M. M., Araus, J. L., and Monneveux, P. (1998). Effects of water deficit on photosynthetic capacity and osmotic adjustment in tetraploid wheats. Photosynthetica 35, 129-138.

Remington, D. L., Thornsberry, J. M., Matsuoka, Y., Wilson, L. M., Whitt, S. R., and Doebley, J. (2001). Structure of linkage disequilibrium and phenotypic associations in the maize genome. Proc. Natl. Acad. Sci. U.S.A. 98, 11479-11484.

Reynolds, M. P., Calderini, D. F., Condon, A. G., and Rajaram, S. (2001a). Physiological basis of yield gains in wheat associated with the LR19 translocation from A elongatum. Euphytica 119, 137-141.

Reynolds, M. P., Trethowan, R., van Ginkel, M., and Rajaram, S. (2001b). "Application of physiology in wheat breeding," in Application of Physiology in Wheat Breeding, eds M. P. Reynolds, J. I. Ortiz-Monasterio, and A. McNab (Mexico: CIMMYT), 2-10.

Reynolds, M. P., Pellegrineschi, A., and Skovmand, B. (2005). Sinklimitation to yield and biomass: a summary of some investigations in spring wheat. Ann. Appl. Biol. 146, 39-49.

Reynolds, M. P., Sayre, K. D., and Rajaram, S. (1999). Physiological and genetic changes in irrigated wheat in the post Green Revolution period and approaches for meeting projected global demand. Crop Sci. $39,1611-1621$

Reynolds, M. P., Skovmand, B., Trethowan, R., and Pfeiffer, W. (2000). "Evaluating a conceptual model for drought tolerance," in Molecular Approaches for Genetic Improvement of Cereals for Stable Production in Water-Limited Environments, eds J.-M. Ribaut and D. Poland (Mexico: CIMMYT), 49-53.

Rharrabti, Y., Villegas, D., García del Moral, L. F., Aparicio, N., El Hani, S., and Royo, C. (2001). Environmental and genetic determination of protein content and grain yield in durum wheat under Mediterranean conditions. Plant Breed. 120, 381-388.

Richards, R. A. (1996). Defining selection criteria to improve yield under drought. Plant Growth Regul. 20, 157-166.

Richards, R. A., Rebetzke, G. J., Condon, A. G., and van Herwaarden, A. F. (2002). Breeding opportunities for increasing the efficiency of water use and crop yield in temperate cereals. Crop Sci. 42, 111-121.

Royo, C., Aparicio, N., Villegas, D., Casadesús, J., Monneveux, P., and Araus, J. L. (2003). Usefulness 
of spectral reflectance indices as durum wheat yield predictors under contrasting Mediterranean conditions. Int. J. Remote Sens. 24, 4403-4419.

Royo, C., García del Moral, L. F., Slafer, G., Nachit, M. M., and Araus, J. L. (2005). "Selection tools for improving yield-associated physiological traits," in Durum Wheat Breeding: Current Approaches and Future Strategies, eds C. Royo, M. M. Nachit, N. Di Fonzo, J. L. Araus, W. H. Pfeiffer, and G. A. Slafer (Binghamton, NY: Haworth Press), 563-598.

Royo, C., Villegas, D., García del Moral, L. F., El Hani, S., Aparicio, N., Rharrabti, Y., et al. (2002). Comparative performance of carbon isotope discrimination and canopy temperature depression as predictors of genotype differences in durum wheat yield in Spain. Aust. J. Agric. Res. 53, 561-569.

Sax, K. (1922). Sterility in wheat hybrids. 11. Chromosome behavior in partially sterile hybrids. Genetics 7, 49-68.

Serraj, R., and Sinclair, T. R. (2002). Osmolyte accumulation: can it really help increase crop yield under drought conditions? Plant Cell Environ. 25, 333-341.
Shearman, V. J., Sylvester-Bradley, R., Scott, R. K., and Foulkes, M. J. (2005). Physiological processes associated with wheat yield progress in the UK. Crop Sci. 45, 175-185.

Singh, A. J., and Byerlee, D. (1990). Relative variability in wheat yields across countries over time. J. Agric. Econ. 41, 21-32.

Slafer, G. A. (2003). Genetic basis of yield as viewed from a crop physiologist's perspective. Ann. Appl. Biol. $142,117-128$

Slafer, G. A., and Andrade, F. H. (1993). Physiological attributes related to the generation of grain yield in bread wheat cultivars released at different eras. Field Crops Res. 31, 351-367.

Slafer, G. A., Araus, J. L., Royo, C., and García del Moral, L. F. (2005). Promising eco-physiological traits for genetic improvement of cereal yields in Mediterranean environments. Ann. Appl. Biol. 146, 61-70.

Tambussi, E. A., Nogués, S., and Araus, J. L. (2005). Ear of durum wheat under water stress: water relations and photosynthetic metabolism. Planta 221, 446-458.

Trethowan, R., Reynolds, M. P., Skovmand, B., and van Ginkel, M. (1998). "The effect of glume pubescence on floret temperature in wheat," 1998 Agronomy Abstracts
(American Society of Agronomy, Baltimore, MD, USA), 161.

van Slageren, M. W. (1994). "Wild wheats: a monograph of Aegilops $L$ and Amblyopyrum (Jaub and Spach) Eig (Poaceae)," in ICARDA/Wageningen Agricultural University Papers 9 (Aleppo Syria/Wageningen, The Netherlands), 512.

Villegas, D., Aparicio, N., Nachit, M. M., Araus, J. L., and Royo, C. (2000) Photosynthetic and developmental traits associated with genotypic differences in durum wheat yield across the Mediterranean basin. Aust. J. Agric. Res. 51, 891-901.

Voltas, J., Romagosa, I., Muñoz, P. and Araus, J. L. (1998). Mineral accumulation, carbon isotope discrimination and indirect selection for grain yield in two-rowed barley grown under semiarid conditions. Eur. J. Agron. 9, 147-155.

Von Bothmer, R., Seberg, O., and Jacobsen, N. (1992). Genetic resources in the Triticeae. Hereditas 116, 141-150.

Xu, X., Yuan, H., Li, S. H., and Monneveux, P. (2007). Relationship between carbon isotope discrimination and grain yield in spring wheat cultivated under different water regimes. J. Integr. Plant Biol. 49, 1497-1507.
Zaharieva, M., and Monneveux, P. (2006). Spontaneous hybridization between bread wheat (Triticum aestivum $\mathrm{L}$ ) and its wild relatives in Europe. Crop Sci. 46, 512-527.

Conflict of Interest Statement: The authors declare that the research was conducted in the absence of any commercial or financial relationships that could be construed as a potential conflict of interest.

Received: 03 May 2012; accepted: 23 October 2012; published online: 16 November 2012.

Citation: Monneveux $P$, Jing R and Misra SC (2012) Phenotyping for drought adaptation in wheat using physiological traits. Front. Physio. 3:429. doi: 10.3389/ fphys.2012.00429

This article was submitted to Frontiers in Plant Physiology, a specialty of Frontiers in Physiology.

Copyright (C) 2012 Monneveux, Jing and Misra. This is an open-access article distributed under the terms of the Creative Commons Attribution License, which permits use, distribution and reproduction in other forums, provided the original authors and source are credited and subject to any copyright notices concerning any third-party graphics etc. 